\title{
Structure and regeneration status of mangrove patches along the estuarine and coastal stretches of Kerala, India
}

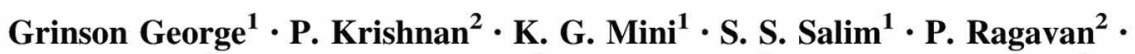 \\ S. Y. Tenjing ${ }^{2} \cdot$ R. Muruganandam $^{2} \cdot$ S. K. Dubey ${ }^{3} \cdot$ A. Gopalakrishnan $^{1} \cdot$ \\ R. Purvaja ${ }^{2} \cdot$ R. Ramesh ${ }^{2}$
}

Received: 3 February 2017/Accepted: 6 November 2017

(c) Northeast Forestry University and Springer-Verlag GmbH Germany, part of Springer Nature 2018

\begin{abstract}
This study presents the structural characteristics and regeneration potential of mangrove patches in the estuarine and coastal areas of Kerala, a tropical maritime state in India. Field surveys were carried out at 46 selected sites during August 2015 to May 2016. In each site, the vegetative structure and regeneration status were assessed using the quadrat method. Altogether 219 quadrates were laid out and a total of 13 true mangrove species, belonging to 5 families and 8 genera, were recorded. The total tree density and stand basal area of the study region was $1678.08 /$ ha and $20.33 \mathrm{~m}^{2} /$ ha respectively. The low basal areas indicate the reduced structural development in mangroves. Of the 13 tree species, Avicennia constitutes $56 \%$ of the total Important Value Index (IVI) and Avicennia officinalis represents $41 \%$ of the IVI in Kerala, followed by Avicennia marina (15\%), Rhizophora mucronata (15\%),
\end{abstract}

Project funding: The work was supported by the Society for Integrated Coastal Management (SICOM), Ministry of Environment, Forest and Climate Change (MoEFCC), Government of India, New Delhi.

The online version is available at http://www.springerlink.com

Corresponding editor: Tao $\mathrm{Xu}$.

Grinson George

grinsongeorge@gmail.com

1 ICAR-Central Marine Fisheries Research Institute, Kochi, Kerala 682018, India

2 National Centre for Sustainable Coastal Management, Ministry of Environment, Forest and Climate Change, Chennai 600025, India

3 Department of Aquatic Environment Management, Faculty of Fishery Sciences, West Bengal University of Animal and Fishery Sciences, Kolkata 700094, India
Sonneratia alba (8\%) Rhizophora apiculata (7\%) and Excoecaria agallocha (7\%). The diameter at breast height $(\mathrm{DBH})$ in the study area revealed that $47 \%$ of the tree species came under the 1-10 cm DBH class. Total sapling and seedling density in Kerala was 2238.35 and 3232.42 individuals/ha respectively. Density of young plants (seedlings + saplings) was only $31 \%$ greater of tree density and varied from 3-63\%, which indicates poor regeneration potential. The Maturity index value (MIV) and complexity index (Ic) value of mangroves were 18.30 and 109.81 respectively. However, the low Ic value $(<10)$ observed in seven out of ten coastal districts indicated poor structural development of mangroves in Kerala. Therefore, locationspecific conservation and management measures, guided by the knowledge on spatial distribution and habitat requirements of mangrove varieties should be taken to preserve the mangrove diversity of Kerala.

Keywords Tree density - Complexity · Quadrat survey · Maritime $\cdot$ Regeneration

\section{Introduction}

Mangroves in India are found along the estuaries and coasts of nine Maritime States and four Union Territories. The mangrove habitat of India is broadly classified into three categories: Deltaic (Eastern Coast Mangroves); Estuarine and Backwater (Western Coast Mangroves); and Insular (Andaman and Nicobar Islands) (Mandal and Naskar 2008). Their overall cover is estimated to be $47,40 \mathrm{~km}^{2}$, of which about $58 \%$ is along the east coast (Bay of Bengal); 29\% along the west coast (Arabian Sea); and the remaining $13 \%$ on the Andaman and Nicobar Islands (FSI 2015). 
Kerala has $590 \mathrm{~km}$ of long narrow coastal line. Mangrove vegetation occurs along the banks of estuarine water bodies and adjacent to the back water channels, in the form of a narrow continuous belt or patches. The regular tidal flooding and fresh water supply from the 41 perennial rivers create a suitable ecological environment leading to the development of mangroves on the fringes of backwaters, estuaries and creeks (Basha 1991). Kannur and Kasaragod districts have the maximum number of mangroves. The other districts are Trivandrum, Kollam, Allappuzha, Kottayam, Ernakulam, Thrissur, Kozhikode, and Malappuram, along with the three identified Ramsar sites, namely Ashtamudi, Sasthamkotta, and Vembanad.

At global level, mangroves are vanishing at fast rate with annual loss of $1-2 \%$ per year, which is 5 times greater than the global forest loss (FSI 2015). India and especially Kerala are not an exception to this trend: as of 1975, some $700 \mathrm{~km}^{2}$ of mangroves in Kerala state have drastically shrunken to $6 \mathrm{~km}^{2}$ by 2013 due to habitat conversion. This degradation lead to serious loss of the biodiversity and carbon stored in these ecosystems (Basha 1991).

According to the latest estimate (FSI 2015), the area under mangrove vegetation in Kerala is $9 \mathrm{~km}^{2}$, which is an increase of $3 \mathrm{~km}^{2}$ area compared to the 2013 assessment. However, more than $80 \%$ of the mangrove plots are in private hands. Therefore, they are under serious threat of destruction caused by anthropogenic activities (Basha 1992). Mangrove floristics of Kerala have been studied since 1678 (Van Rheede 1678-1693). However, the total number of true mangrove species in Kerala is under dispute as in other regions. Further, few attempts were made in the past to understand the structural characteristics and attributes of mangroves of Kerala (Nameer et al. 1992; Suresh Kumar and Mohan Kumar 1997; Rahees et al. 2014; Vijayan et al. 2015; Rani et al. 2016).

Management of the fast-declining mangroves requires understanding of the structural complexity (Dislich and Pivello 2002). Considering these facts, the present study was undertaken to provide a comprehensive account on the structural aspects of mangroves in Kerala.

\section{Materials and methods}

\section{Study area and data collection methods}

The study was carried out in all major mangrove habitats in Kerala and 46 sites were selected based on receptiveness, importance, and accessibility (Fig. 1). Selected sites were studied from June 2014 to March 2015. In each site, multiple line transects $(100 \mathrm{~m})$ were laid perpendicular to the waterfront at minimum $50 \mathrm{~m}$ intervals between adjacent transects. Quantitative data on mangrove vegetative

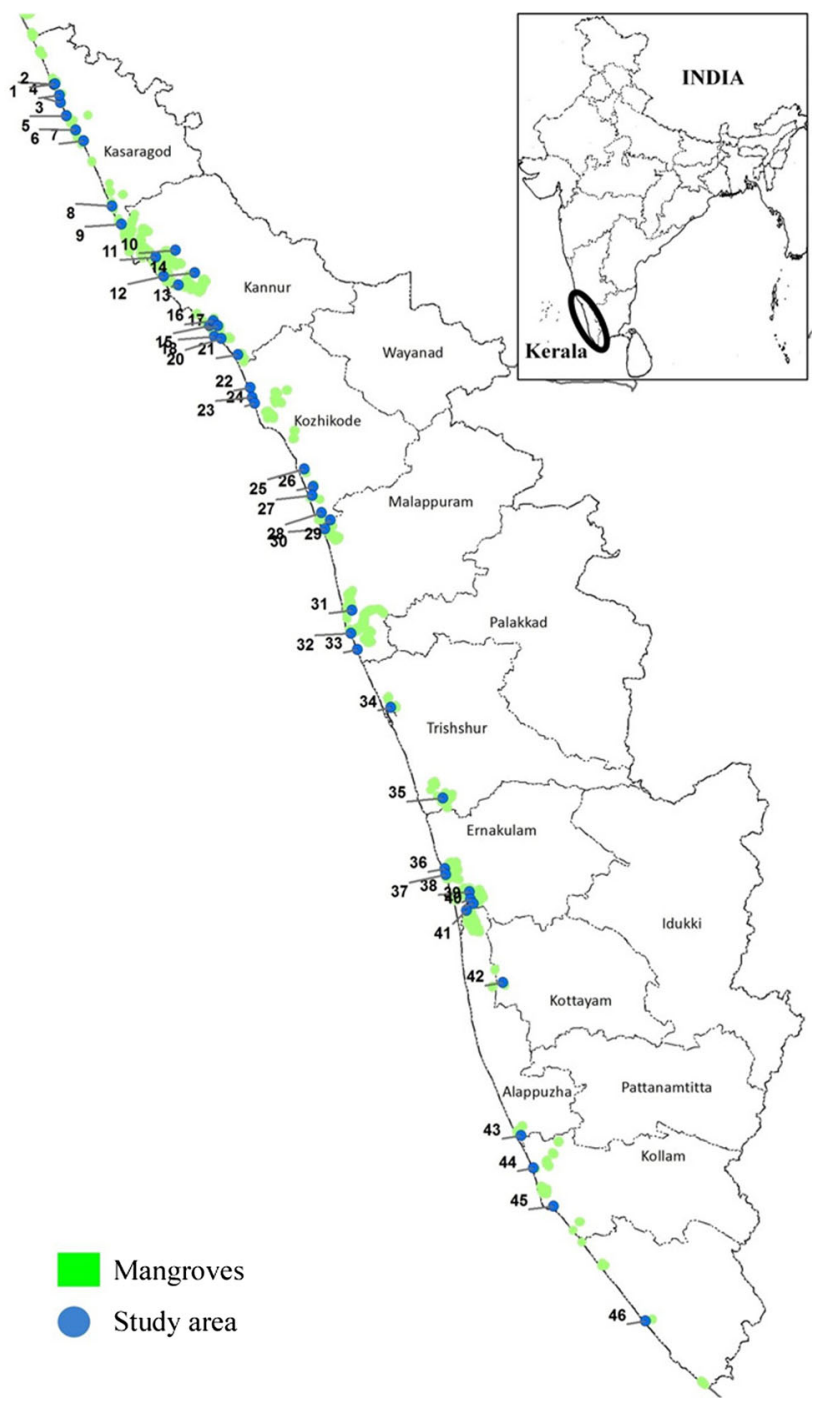

Fig. 1 Map showing the mangrove stands and the study sites in Kerala

structure was collected by laying quadrats $(10 \times 10 \mathrm{~m})$ laid along each of the line transects at 0,50 , and $100 \mathrm{~m}$. Altogether 219 quadrats were determined.

Within each plot, all mangroves were identified to variety level and counted according to three maturity categories as described by Menon (2006), namely, trees ( $>4 \mathrm{~m}$ height), saplings ( $>1$ to $\leq 4 \mathrm{~m}$ height) and seedlings (plant $\leq 1 \mathrm{~min}$ height). Vegetation measurements, including tree height and DBH were noted for all trees. Species wise count data were collected for seedlings and saplings in each quadrat studied.

\section{Data analysis}

On the basis of data obtained from quadrats, the forest structural parameters-such as stem density, relative density, abundance, frequency, relative frequency, basal area, 
and relative basal area-were calculated for the community analysis. The importance value index (IVI) for the tree species was determined as the sum of the relative frequency, relative density, and relative dominance (Curtis 1959). In this study, relative abundance was calculated based on the basal area of individual trees using DBH. Apart from this, the following univariate measures-including Shannon-Wiener diversity index $\left(\mathrm{H}^{\prime}\right)$ (Shannon and Weaver 1963), Margalef's species richness (d) (Margalef 1978), Pielou's evenness (J') (Pielou 1966), Simpson dominance (D) (Simpson 1949), Complexity Index (Holdridge 1967; Pool et al. 1977), Beta diversity ( $\beta$-diversity) (Whittaker 1972), Maturity Index Value (Pichi-Sermolli 1948; Nabi et al. 2012) and Jackknife estimate of species richness (Heltshe and Forrester 1983)—were analyzed.

Niche width was estimated to ascertain the adaptability of different mangrove species to tolerate conditions at the interface between different habitat types (Levins 1968). Variation patterns in community structure were evaluated using the multivariate method-grouping analysis (Cluster) based on the Bray-Curtis similarity index and ordination through non-metric multi-dimensional scaling (MDS). The aim was to detect spatial variation in the density of mangroves by using PRIMER v6 program (Clarke and Gorley 2006). The square-root transformed mangrove species density data was used for PRIMER analyses.

\section{Results}

\section{Mangrove species diversity in Kerala}

In the present study, a total of 13 mangrove tree species belonging to five families and eight genera were observed (Table 1). Among the five families, the number of species represented from the family Rhizophoraceae was the highest (7 species), followed by Acanthaceae and Sonneraticeae ( 2 species each). The Shannon diversity index and Pielou's evenness index for Kerala was 1.94 and 0.75 respectively, indicating high species diversity.

Among the 10 districts with mangroves in Kerala, the maximum number of species (10) was observed in Ernakulam, followed by Kasaragod, Kannur, and Malappuram (Table 1). The tree species-R. mucronata, S. alba, A. officinalis, A. marina, $R$. apiculata, and Bruguiera cylindrica - are almost equally abundant while Bruguiera gymnorhiza and B. sexangula have low relative abundance.

\section{Structural features}

In the present study, 15,656 plants were counted, which comprised $31.31 \%$ saplings, $45.22 \%$ seedlings, and $23.47 \%$ trees. The total tree density and stand basal area in Kerala was $1678.08 /$ ha and $20.33 \mathrm{~m}^{2} / \mathrm{ha}$, respectively. Of the 13 mangrove species recorded, the IVI for A. officinalis was highest $(41 \%)$ and the genus Avicennia alone constituted $56 \%$ of the IVI (Fig. 2). This shows the dominance of Avicennia species in Kerala. Next to Avicennia, $R$. mucronata constituted $15 \%$ of the IVI followed by $R$. apiculata, S. alba, and E. agallocha. All other species constituted less than $5 \%$ of IVI, which shows the rarity of the species in Kerala. Of the eight coastal districts, mangroves of Thrissur and Thiruvananthapuram were represented by single species, viz., $R$. mucronata and $S$. caseolaris respectively. Tree density and basal area were the highest at Kozhikode, followed by Kannur and Kasaragod (Fig. 3). Based on IVI, it was found that in all other mangrove areas, Avicennia species were dominant, except for Thiruvananthapuram and Thrissur. This showed the overall dominance of Avicennia species in Kerala.

The frequency of mangrove trees belonging to the $1-10 \mathrm{~cm}$ DBH category was the highest in Kerala. It was also evident that the number of tree stands gradually decreased with the increase in DBH classes beyond $1-10 \mathrm{~cm}$ (Fig. 4). This inverse " $\mathrm{j}$ " shaped distribution is characteristic of a balanced forest structure with uneven aged trees with the $<10 \mathrm{~cm}$ DBH class having the maximum density and then declining as the DBH increases. The mangrove species in class intervals of $10 \mathrm{~cm}$ indicated that about $47 \%$ of trees occurred in $1-0 \mathrm{~cm}$ class, followed by $45 \%$ of trees in the $11-20 \mathrm{~cm}$ class. Of the 13 tree species, $R$. mucronata had the maximum representation in the 1-10 cm class, whereas A. officinalis had the highest in the $11-20 \mathrm{~cm}$ and $21-30 \mathrm{~cm}$ classes. Further, the individuals of A. officinalis were present in all of the DBH class distributions (Fig. 5).

\section{Regeneration status}

Total sapling and seedling density in entire Kerala was 2238.35 and 3232.42 individuals/ha respectively. Except for Alappuzha and Kollam, in all of the districts, seedling density was higher than that of sapling. Seedling and sapling density were highest at Kollam and lowest at Thiruvananthapuram. The density of young plants (seedling + sapling) was less than 50\% of total tree density (Fig. 6a) in all the coastal districts of Kerala, except Thiruvananthapuram. Among the 13 tree species, the seedling and sapling density was highest for $A$. officinalis followed by A. marina, R. apiculata, R. mucronata, and $E$. agallocha (Fig. 6b).

\section{Forest structure indices}

The Shannon diversity index $\left(\mathrm{H}^{\prime}\right)$, Simpson dominance index (D), Margalef richness index (r) and Peilou's 


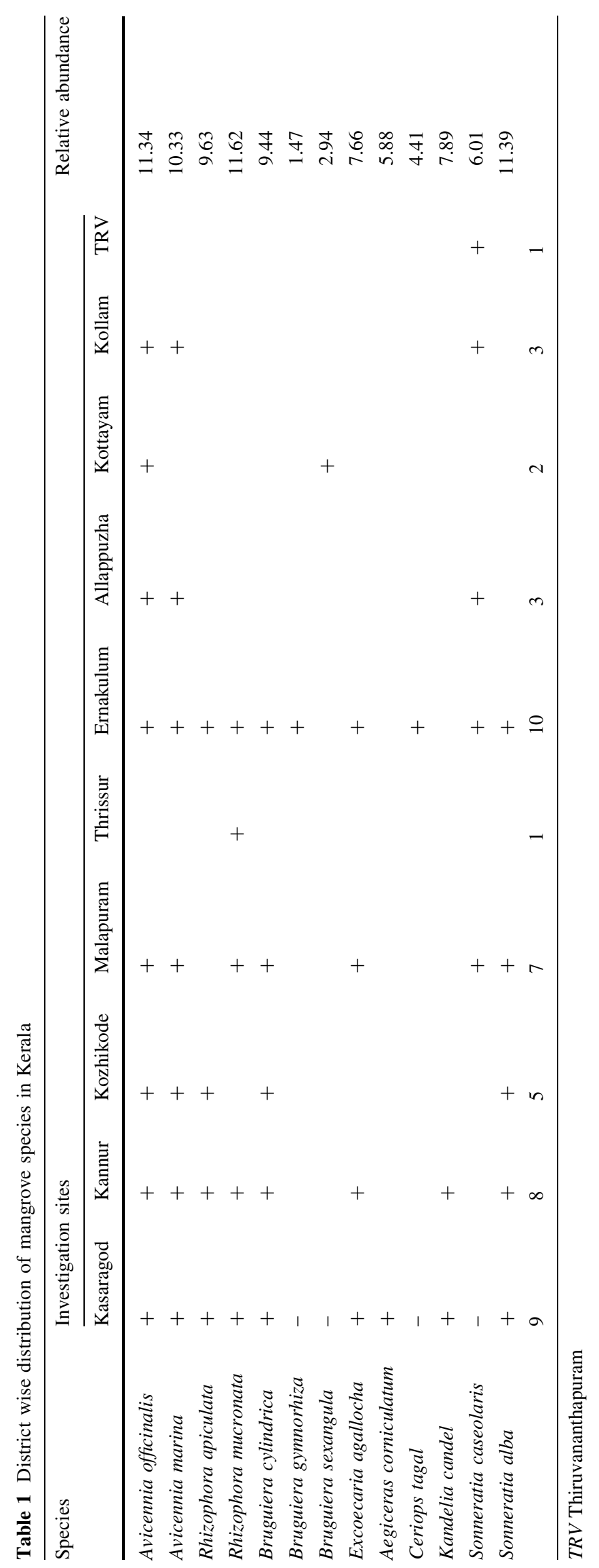




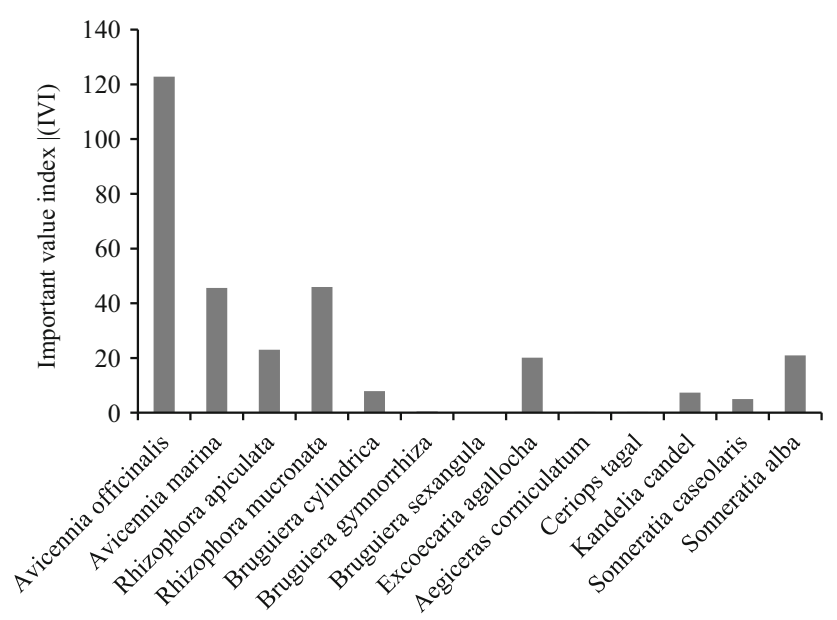

Fig. 2 Species-wise Important Value Index (IVI) of mangroves in Kerala

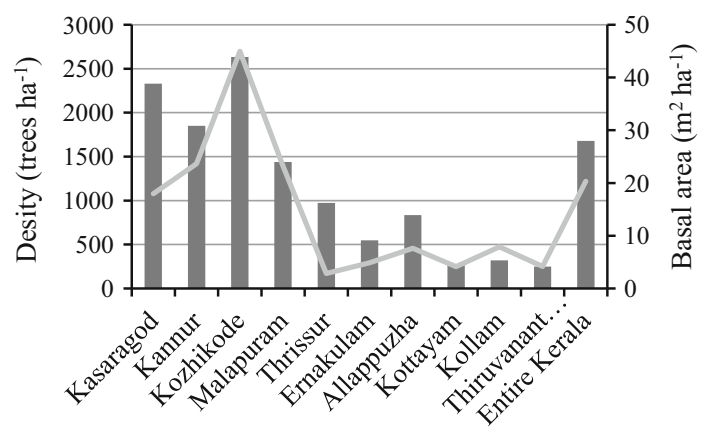

Fig. 3 District-wise tree density and basal area of mangroves in Kerala

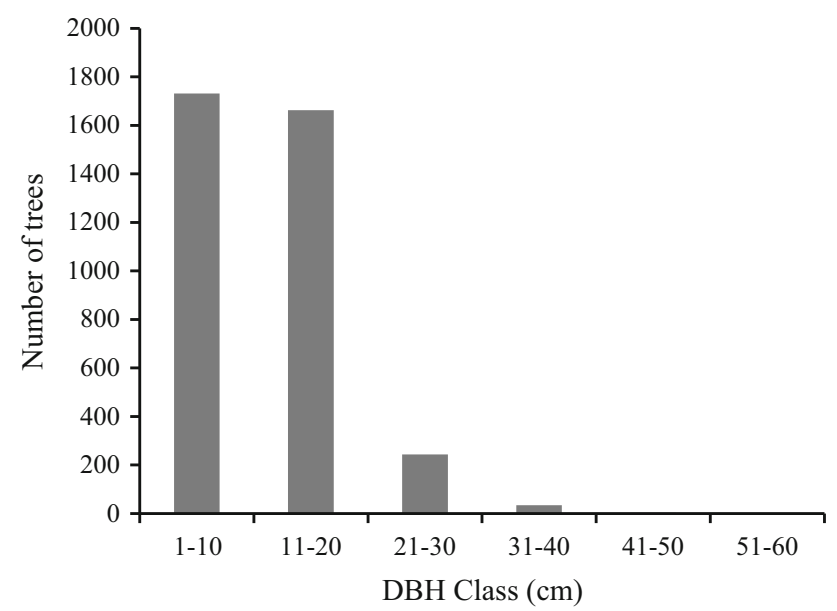

Fig. 4 Frequency distribution of mangrove trees in Kerala based on their Diameter at Breast Height (DBH)

evenness index (J') were $1.94,0.20,1.46$ and 0.75 , respectively (Table 2). While the species richness index was high at Ernakulam (1.76), evenness and Shannon diversity index were low, indicating unequal abundance of certain mangrove species in Ernakulam. In contrast, the

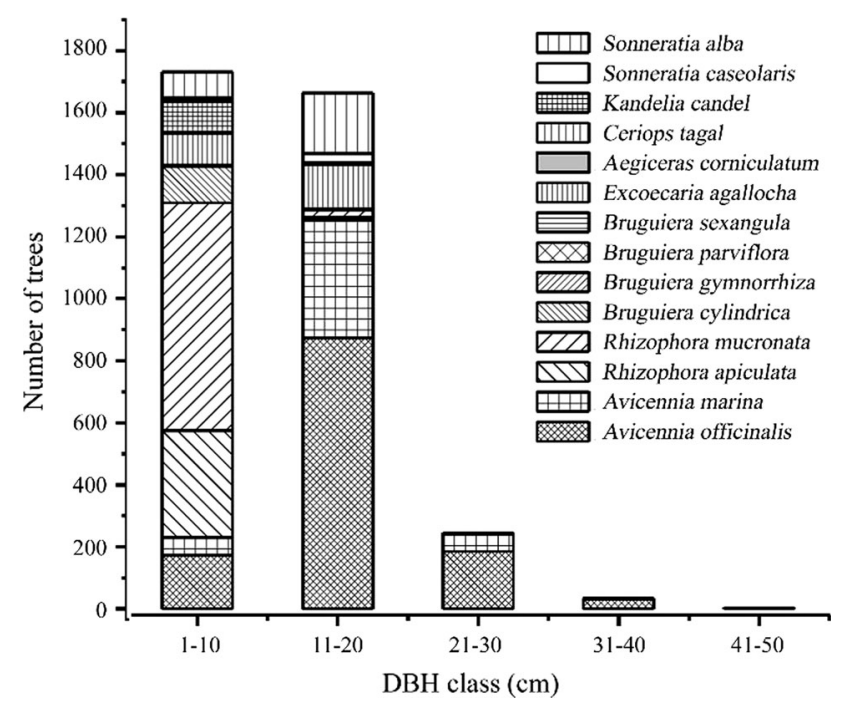

Fig. 5 Species-wise DBH class distribution of mangrove in Kerala
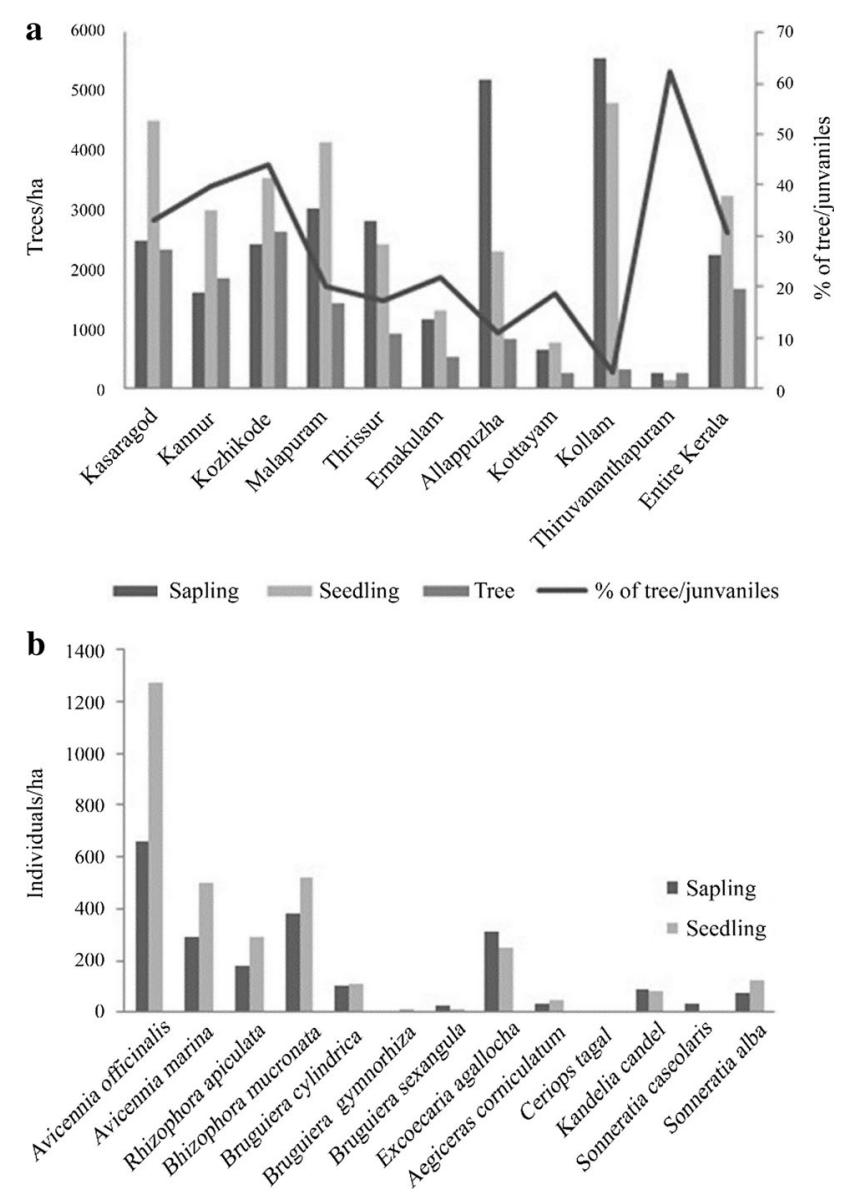

Fig. 6 Tree, sapling and seedling densities of mangroves in Kerala: a District-wise and b Species-wise

Shannon diversity and evenness index was high at Allappuzha (2.12 and 1.34, respectively), while the species richness was low. 
Table 2 Forest structure indices of mangroves in Kerala

\begin{tabular}{|c|c|c|c|c|c|c|c|c|c|c|c|}
\hline \multirow[t]{2}{*}{ Forest structure indices } & \multicolumn{10}{|c|}{ Investigation sites } & \multirow[t]{2}{*}{ Entire Kerala } \\
\hline & KAS & KAN & $\mathrm{KOZ}$ & MAL & TRI & ERN & ALP & KOT & KOL & TRV & \\
\hline Jack Knife index & 10.95 & 8.00 & 5.00 & 8.87 & 1.00 & 10.97 & 3.00 & 2.67 & 3.00 & 1.00 & 15.99 \\
\hline Complexity index & 162.57 & 0.00 & 210.89 & 81.93 & 5.67 & 9.97 & 10.13 & 1.74 & 5.02 & 0.87 & 109.81 \\
\hline Simpsons measure of evenness & 0.36 & 0.34 & 0.40 & 0.53 & 1.38 & 0.28 & 0.97 & 0.84 & 0.82 & 0.78 & 0.31 \\
\hline Simpsons index & 0.19 & 0.20 & 0.28 & 0.28 & 0.28 & 0.46 & 0.14 & 0.55 & 0.18 & 0.64 & 0.20 \\
\hline Shannon Weiner diversity index & 1.81 & 1.82 & 1.58 & 1.69 & 1.52 & 1.19 & 2.12 & 0.93 & 1.89 & 0.54 & 1.94 \\
\hline Margalef richness Index & 1.16 & 0.96 & 0.61 & 1.12 & 0.00 & 1.76 & 0.51 & 0.48 & 0.58 & 0.00 & 1.46 \\
\hline Pielous evenness index & 0.82 & 0.87 & 0.98 & 0.87 & 0.00 & 0.51 & 1.93 & 1.34 & 1.72 & 0.00 & 0.75 \\
\hline Maturity index value & 38.24 & 31.41 & 41.54 & 23.81 & 42.86 & 22.67 & 50.00 & 50.00 & 33.33 & 100.00 & 18.30 \\
\hline
\end{tabular}

KAS Kasaragod, KAN Kannur, KOZ Kozhikode, MAL Malapuram, TRI Thrissur, KRN Ernakulum, ALP Allappuzha, KOT Kottayam, KOL Kollam, $T R V$ Thiruvananthapuram

After comparing diversity indices, it was apparent that mangroves in Kannur were the most diverse, followed by Kasaragod, Malappuram, and Ernakulam. The Maturity Index Value (MIV) and Complexity Index (Ic) value of mangroves of Kerala were 18.30 and 109.81, respectively. MIV was highest in Thiruvananthapuram district (100), while Ic was the highest in Kozhikode (210.89). The estimated Jack knife index was 15.99 (Table 2). The mangroves areas in Kerala were found to have $I c$ value of $<14$ (Table 2), except in the Kasaragod, Kozhikode, and Malappuram districts that showed the existence of stress and disturbance in these areas. The MIV of the Kerala Mangroves ranged from 23.81 to 50.00, which was less than the maximum value (i.e. 100), depicting their low degree of maturity.

Bray-Curtis cluster analysis, based on the species composition and IVI (Fig. 7), grouped ten districts of Kerala into three major clusters. Thiruvananthapuram, Thrissur, and Kottayam are grouped into one cluster as they represented by one or two species, whereas Allappuzha and Kollam are grouped into another cluster, having three

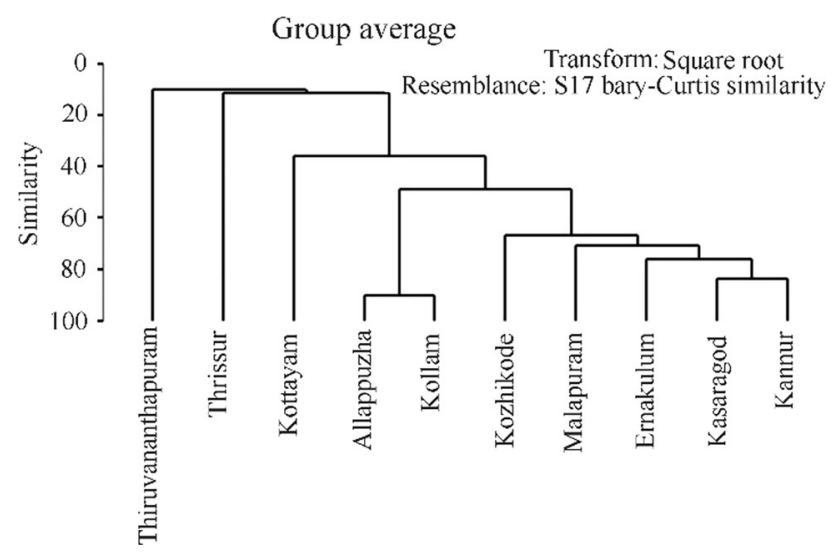

Fig. 7 Dendrogram showing similarity among the study sites in Kerala species each. Districts having high species richness, e.g., Kozhikode, Kasaragod, Ernakulam, and Malappuram, were grouped in one cluster. Based on the species cluster and the accompanying MDS (Fig. 8a, b), the abundance and distribution of mangroves species in Kerala could be divided into five groups, having 20\% similarity: (1) Group 1 included $A$. officinalis and A. marina, which were widely represented in the Kerala mangroves and constitute the major portion (about 50\%) of the IVI, (2) Group 2 included $R$. mucronata, $R$. apiculata, B. cylindrica, E. agallocha and $S$. alba, and these species were found in few districts of Kerala with equal abundance, (3) Group 3 included Aegiceras corniculatum and Kandelia candel, (4) Group 4 included B. gymnorhiza and Ceriops tagal, whereas Group 5 had only B. sexangula, (5) Species in Group 3-5 had restricted distribution and low relative abundance.

\section{Discussion}

\section{Species diversity}

The earliest reference on mangrove floristics in Kerala (Van Rheede 1678-1693) reported eight mangrove species: A. corniculatum, A. officinalis, E. agallocha, K. candel, Lumnitzera racemosa, Rhizophora cyclindrica $(=R$. apiculata), and $R$. mucronata. Subsequently Drury (1864) had described a few more plants, apart from the ones listed by Van Rheede (1678-1693) namely, Eriops candolleanus (=C. tagal) and Bruguiera eriopetala (= Bruguiera sexangula).

Later Beddome (1866), Hooker (1872), Bourdillon (1908), Rama Rao (1914) and Gamble and Fischer (19151935) described the distribution of mangrove species as part of their forest floral assessment. Consequently, there were many studies on the occurrence of mangrove flora along the Kerala coasts (Troup 1921; Govinda-Menon 1930; Erlanson 
Fig. 8 a Hierarchical clustering (Bray-Curtis similarity) of mangrove species based on the density and IVI, b nMDS ordination of mangrove species based on the density and IVI a

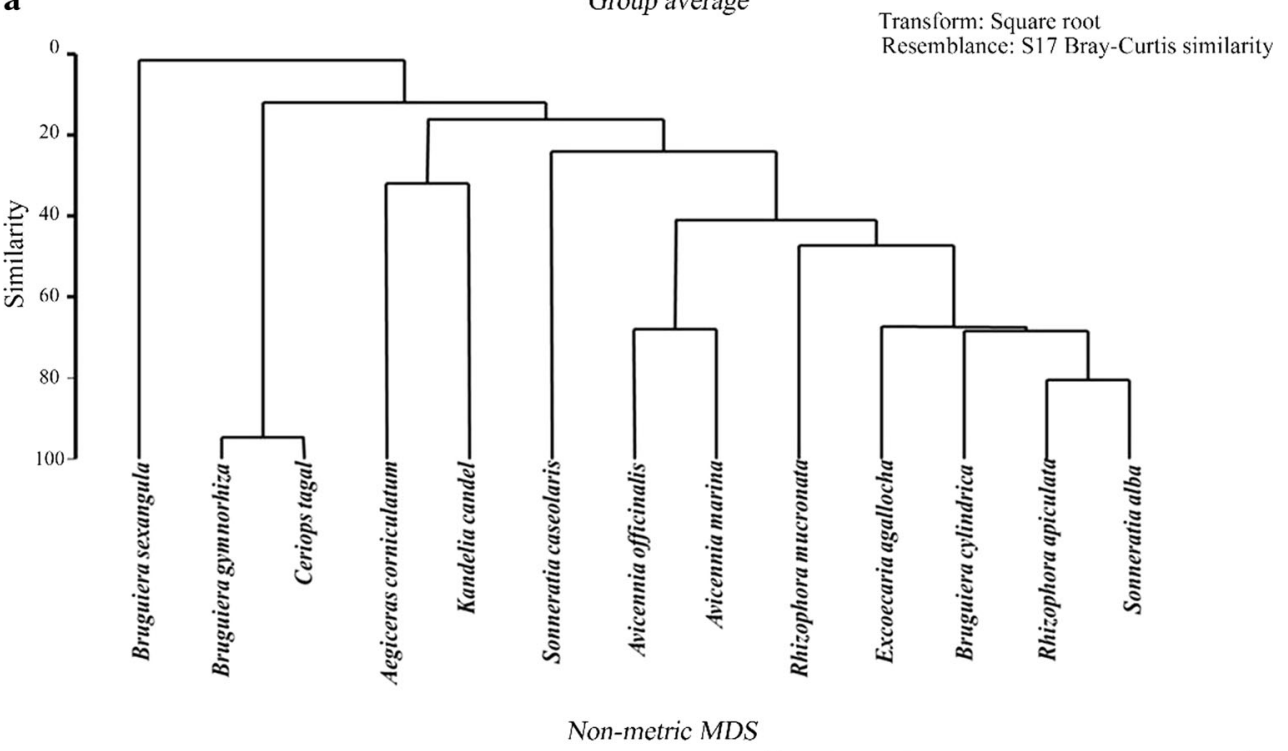

b

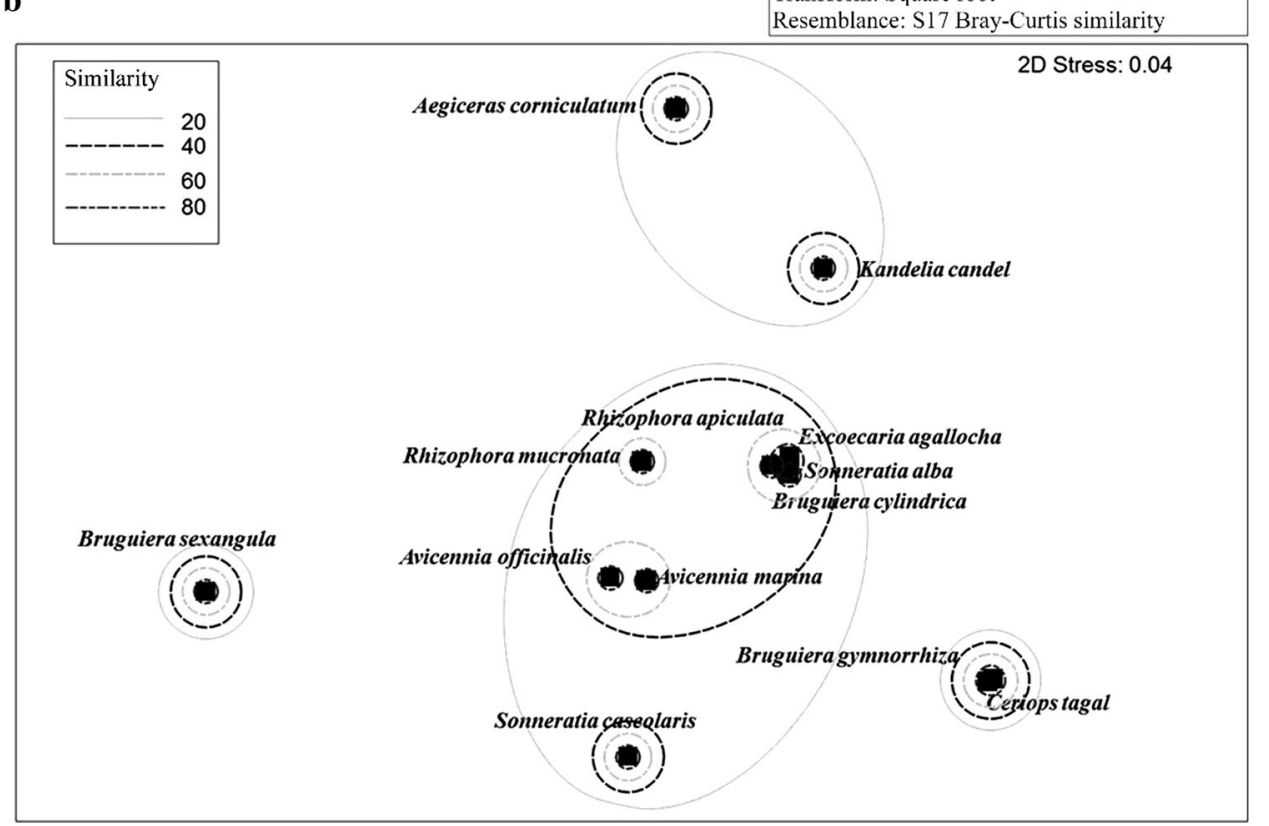

1936; Mudailarm and Kamath 1954; Thomas 1962; Rao and Sastry 1974; Blasco 1975; Kurian 1980; Ramachandran et al. 1986; Ramachandran and Mohanan 1987). However, their efforts did not provide the comprehensive account on floristics and distribution of mangroves in Kerala.

Ramachandran et al. (1986) made the first inventory of the mangrove flora, mapped them along the entire coast of Kerala and reported 18 true mangrove species.That said, the distributional status of true mangrove species in Kerala was not provided. Later, Basha (Basha 1991, 1992) provided the comprehensive account on mangrove flora of Kerala, listing 18 true mangrove species and also their status and distribution in entire Kerala coast.
In the recent past, Anupama and Sivadasan (2004) reported 15 true mangrove species and Kathiresan (2008) reported 19 true mangroves species. Vidyasagaran and Madhusoodanan (2014) reported 15 true mangrove species from Kerala. The variation in mangrove floristics of Kerala in earlier studies could be attributed to the uncertainty in the classification schemes of mangroves. As per the recent review on mangrove floristics, of India based the classification of Polidoro et al. (2010), a total of 19 species belonging to 12 genera and 8 families have been recognized as true mangroves species in Kerala (Ragavan et al. 2016).

The total number of species recorded in the present study does not include Acanthus species, L. racemosa, E. 
agallocha and Acrostichum species. As the current study was designed to provide the structural characteristics of tree mangrove species, the mangrove associate, Acrostichum species were excluded; L. racemosa and E. agallocha, which had a very restricted distribution in Kerala, were not found in this study. The reduction in species number could be attributed to the intensity of research efforts, sampling locations, and species considerations (Van Nguyen et al. 2013; Whitmore 1988).

\section{Vegetative structure}

Stand density and tree height are important for biomass and coastal protection functions, as well as resilience ability to absorb or recover from environmental impacts (Kathiresan et al. 2016). The tree density (250-2634.60/ha) and basal area $\left(2.84-44.96 \mathrm{~m}^{2} \mathrm{ha}^{-1}\right)$ of mangroves of Kerala observed in this study were similar to earlier studies (e.g. Nameer et al. 1992; Suresh Kumar and Mohan Kumar 1997; Rahees et al. 2014; Vijayan et al. 2015). However, Rani et al. (2016) reported high density (7680-11,760/ha) and basal area $\left(0.16-94.32 \mathrm{~m}^{2} \mathrm{ha}^{-1}\right)$ from Cochin mangroves, which could be attributed to the inclusion of Acanthus and Acrostichum species.

Basal area is an indicator for measuring forest-stand development and understanding species population, biomass and productivity in response to stress factors (Twilley 1998). Pristine mangrove forests with minimal impacts have a basal area of $>25 \mathrm{~m}^{2} \mathrm{ha}^{-1}$ (Komiyama et al. 2008; Kauffman et al. 2011); secondary forest has been found to have basal area of around $15 \mathrm{~m}^{2} \mathrm{ha}^{-1}$ (Komiyama et al. 2008; Cavalcanti et al. 2009); and disturbed forests show basal areas of $<10 \mathrm{~m}^{2} \mathrm{ha}^{-1}$ (Komiyama et al. 2008). The total stand basal area in mangroves of Kerala was $20.33 \mathrm{~m}^{2} \mathrm{ha}^{-1}$, which indicated the secondary succession.

Among the coastal districts, the basal area of mangroves in Kozhikode was $>25 \mathrm{~m}^{2} \mathrm{ha}^{-1}$, indicating their pristine nature. Kannur, Kasaragod, and Malappuram had basal areas around $15 \mathrm{~m}^{2} /$ ha, which showed secondary succession, whereas all other mangrove areas in Kerala were found to have a basal area $>10 \mathrm{~m}^{2} / \mathrm{ha}$, indicating the distributed nature of mangrove forest with low structural development.

Further, more than 50\% of basal areas and IVI were represented by Avicennia species, which showed the dominance of this species in mangroves of Kerala as already reported by various researchers (Nameer et al. 1992; Suresh Kumar and Mohan Kumar 1997; Rahees et al. 2014; Vijayan et al. 2015; Rani et al. 2016). Usually the structural development of the pioneer species of mangrove ecosystem is considered for checking the maturity of that forest and after considering the overall structural data (Pellegrini et al. 2009).
It was observed that the pioneer species A. officinalis having mature structural development in most of the mangrove areas in Kerala. The structural complexity in forest stands is a function of tree species richness, among other variables (Holdridge et al. 1971; Kairo et al. 2002; Bosire et al. 2003). But the monospecies dominance results in the reduction of structural complexity and ecosystem services. $I c$ is often used for quantitative description of the structural complexity of the tropical vegetation (Pool et al. 1977). The estimated $I c$ values and MIV in Kerala showed some similarity with earlier studies (Pool et al. 1977; Fromard et al. 1998; Amarasinghe and Balasubrananiam 1992; Upadhyay and Mishra 2014; Joshi and Ghose 2014). Singh et al. (1990) and Singh and Odaki (2004) reported Ic values of 6.9-14.1 for disturbed and 87.1-260 for undisturbed mangroves of Andaman Islands of India.

In the present study, the $I c$ values ranged from 0.87 to 210.89 and for the entire Kerala state, it was 109.81. This indicated that the mangroves patches along the Kerala coast are generally undisturbed, but with regional exceptions. However, the $I c$ value was less than 10 in seven coastal districts, except Kannur, Kasaragod and Malappuram, indicating low structural development and prevalence of disturbances in these mangrove stands.

Earlier studies also reported the degraded nature of mangroves of Kerala (Basha 1991, 1992; Nameer et al. 1992; Suresh Kumar and Mohan Kumar 1997; Rahees et al. 2014; Vijayan et al. 2015; Rani et al. 2016; Khaleel 2005). All of the mangrove areas, except Thiruvananthapuram, had low MIVs, which indicated the absence of matured forest. Thus, the mangrove habitats in Kerala illustrate the presence of uneven, aged mixed mangrove forest with well and low structural development based on the overall stand basal area.

The density and stand basal area values from the Kerala mangroves were comparable with the mangrove forests in India and other parts of the world (Table 3). While the tree density in Kerala (250-2634.60 trees/ha) was lower than that found in Thailand (Chasang 1984; Macintosh et al. 2002), Papua New Guinea (Robertson et al. 1991; Johnstone 1983), Belizean coast, Central America (Murray et al. 2003) and Indonesia (Hinrichs et al. 2009), it was higher than that in Srilanka (Kala Oya estuary) and Malaysia (Kelantan delta) (Table 3).

Within India, the tree density of Kerala mangroves was lower than the mangroves of Gujarat, Andhra Pradesh, Odisha, and West Bengal, and higher than that of Pichavaram and ANI (Table 3). The stand basal area in the Kerala mangroves showed similarity with Kala oya estuary (Srilanka), Keltan delta (Malaysia) and Zambezi River Delta (Brazil) and higher than the other mangrove habitats of India (Table 3). 
Table 3 Comparison of mangrove tree density and basal area in different mangrove forests of the world

\begin{tabular}{|c|c|c|c|c|}
\hline Mangrove forest & Country/region & $\begin{array}{l}\text { Density (trees } \\
\mathrm{ha}^{-1} \text { ) }\end{array}$ & Basal area $\left(\mathrm{m}^{2} \mathrm{ha}^{-1}\right)$ & References \\
\hline Kala Oya estuary & Sri Lanka & $10-528$ & $27.10-48.25$ & Perera et al. (2013) \\
\hline Kelantan delta & Peninsular Malaysia & $790-1360$ & $1.4-49$ & Satyanarayana et al. (2010) \\
\hline Sibuti mangrove forest & Malaysia & $1600-2340$ & $171.10-201.83$ & Shah et al. (2015) \\
\hline Bocas del Toro archipelago & Panama & $4730-33,570$ & $6.8-30.1$ & Lovelock et al. (2005) \\
\hline Ceará state & Brazil & & $0.47-2.9$ & Maia and Coutinho (2012) \\
\hline Zambezi river delta & Brazil & $158-6000$ & $1.2-40.8$ & Trettin et al. (2016) \\
\hline Segara Anakan lagoon & Indonesia & $10-2880$ & $0.02-10.28$ & Hinrichs et al. (2009) \\
\hline Samar Island & Philippines & $1500-3000$ & $5.0-22.78$ & Mendoza and Alura (2001) \\
\hline Mundra coast and Kharo creek & Gujarat, India & $1820-4325$ & - & Sawale and Thivakaran (2013) \\
\hline Coringa mangrove forest & $\begin{array}{l}\text { Andhra Pradesh, } \\
\text { India }\end{array}$ & $90-17,310$ & $0.01-120$ & Satyanarayana et al. (2009) \\
\hline Coringa mangrove forest & $\begin{array}{l}\text { Andhra Pradesh, } \\
\text { India }\end{array}$ & 6140 & - & Azariah et al. (1992) \\
\hline Kakinada Bay & $\begin{array}{l}\text { Andhra Pradesh, } \\
\text { India }\end{array}$ & $470-17,310$ & $10-109$ & Satyanarayana et al. (2002) \\
\hline Krishna mangroves & $\begin{array}{l}\text { Andhra Pradesh, } \\
\text { India }\end{array}$ & $734-5009$ & & Venkanna and Narasimha Rao (1993) \\
\hline Godavari mangroves & $\begin{array}{l}\text { Andhra Pradesh, } \\
\text { India }\end{array}$ & $874-6895$ & & Venkanna and Narasimha Rao (1993) \\
\hline Bhitarkanika & Odisha, India & $2012-3586$ & $3.17-7.55$ & Upadhyay and Mishra (2014) \\
\hline Lothian Island & West Bengal, India & $912-7031$ & $4.2-19.2$ & Joshi and Ghose (2003) \\
\hline Lothian Island & West Bengal, India & $4723-23,751$ & $4.9-20.3$ & Joshi and Ghose (2014) \\
\hline Andaman and Nicobar Islands & India & $487-2383$ & - & Ragavan et al. (2015) \\
\hline Pichavaram & Tamil Nadu, India & 1641 & & Kathiresan et al. (2016) \\
\hline Kollam mangroves & Kerala, India & $267-3760$ & $1.58-29.70$ & Vijayan et al. (2015) \\
\hline Cochin estuary & Kerala, India & $7680-11,760$ & $0.16-94.32$ & Rani et al. (2016) \\
\hline Puduvyppu mangroves & Kerala, India & $11-700$ & $0.1-2.0$ & Nameer et al. (1992) \\
\hline Puduvyppu mangroves & Kerala, India & $74-2834$ & $0.16-10.40$ & Suresh Kumar and Mohan Kumar (1997) \\
\hline Kadalundi mangroves & Kerala, India & $107-5014$ & $0.30-46.69$ & Rahees et al. (2014) \\
\hline Entire Kerala & India & $250-2636$ & $2.84-44.96$ & Present study \\
\hline
\end{tabular}

The wide variation in density and basal areas of different studies could be partially attributed to the variation in the classification criteria of mangroves. For example, Satyanarayana et al. (2002) classified plants $<4 \mathrm{~m}$ height as trees, while Narasimha Rao (2012) measured the DBH just above the ground level, as, in his study area (Andhra Pradesh), larger tree species were less. Further, most forest structure assessments were concentrated only in few areas in the states and the inclusion of coastal vegetation and marsh plant also contributed to the exaggerated values.

\section{Regeneration status}

The density and abundance of saplings and seedlings indicate the regeneration potential (Twilley 1995; Pallardy 2008). Seedling recruitment and survivorship principally drive the population growth (Burns and Ogden 1985;
Krauss et al. 2008) and thus determine the quality of crop and productivity of forest stands (Srivastava and Bal 1984). Regeneration potential of mangroves is usually measured using sapling and seedling abundance data (Ashton and Macintosh 2002). Good regeneration potential is determined based on two criteria: (1) if the total number of saplings and seedlings is greater than $50 \%$ of mature trees per hectare (Gan 1995) and (2) if a minimum of 2500 seedlings are present in one-hectare area of the forest (Srivastava and Bal 1984). The first criterion factors the density of mature trees responsible for seedling production, while the second criterion does not.

In the present study, the density of young plants (seedlings + saplings) was only $30.67 \%$ higher than that of tree density, which suggested that the mangroves in Kerala had poor regeneration potential (as per the first criterion, above). On the contrary, the seedling density was $>2500$ 
individuals/ha in Kasaragod, Kannur, Kozhikode, and Malappuram and the mean seedling density was $2701 \pm 1600$, which suggested good regeneration potential of the mangroves in Kerala (as per the second criterion, above). Further, the occurrence of a large proportion of saplings over seedlings also implied the high growth rate of seedlings. However, as the density of young plants represented $<50 \%$ of tree density in all the coastal districts of Kerala except Thiruvananthapuram, it is concluded that the mangroves in Kerala possessed poor regeneration potential.

\section{Conclusions}

Mangroves in Kerala represent $0.19 \%$ of the total mangroves of India, with total areas of just 9 square $\mathrm{km}^{2}$, but they represent $41 \%$ of the true mangrove species in India. In the present study, 13 mangrove species, belonging to 5 families and 8 genera were recorded from Kerala and it was found that mangroves in Kerala varied in diversity, density, and structural development.

The structural characteristics of the mangrove forest revealed the presence of uneven, aged mixed mangrove forest. Considering the overall structural data, it could be concluded that the mangroves in Kasaragod, Kannur, Kozhikode, and Malappuram have high species diversity and considerable structural development. Though the mangroves of Ernakulam had high species richness, monospecies dominace and lows basal area indicated poor structural development and uneven species abundances. Mangroves in other districts have low species diversity and structural development. Further the density of young plants less than $50 \%$ of tree density, suggested that the mangroves in Kerala had poor regeneration potential.

The mangrove ecosystems are threatened globally due to various anthropogenic activities and climate change. Further, the species diversity of Indian mangroves is under constant flux due to both natural (e.g. erosion, aggradations) and anthropogenic forces, possibly leading to changes in floristic composition and local extinction of some species. Forest structure determines biodiversity and the ecosystem function and is closely correlated with stress, but in the Indian context, studies on mangrove forest structure are very limited. Since mangroves are species poor compared to other tropical ecosystems, the knowledge on species composition and structural characteristics of mangrove forest in an area are essential for the better management of mangroves.

So far, the conservation regimes in most countries including India have laid emphasis on increasing the area of mangroves and most of the restoration/rehabilitation efforts are undertaken based on inadequate species-specific information. The contemporary mangrove conservation regime on global scale advocates "early detection and preemptive rehabilitation", for successful management. And to achieve this, location-specific and species-specific information on the mangrove stands are the prerequisites (Lewis et al. 2016). The data provided in this study would be a step toward this goal and aid in location-specific conservation planning for proper management and rejuvenation of the mangroves in Kerala.

Acknowledgements The study was undertaken as a part of a national research project, "Delineation of ecologically sensitive areas (ESA) and critically vulnerable coastal areas (CVCA) along the coast of India," supported by the Society for Integrated Coastal Management (SICOM), Ministry of Environment, Forest and Climate Change (MoEFCC), Government of India, New Delhi. The framework for the study was developed by National Centre for Sustainable Coastal Management, MoEFCC, Chennai and the field studies were undertaken by ICAR-Central Marine Fisheries Research Institute, Kochi, Kerala.

\section{References}

Amarasinghe MD, Balasubrananiam S (1992) Structural properties of two mangrove forest stands on the northwestern coast of Sri Lanka. Hydrobiologia 247:17-27

Anupama C, Sivadasan M (2004) Mangroves of Kerala, India. Rheedea 14:9-46

Ashton EC, Macintosh DJ (2002) Preliminary assessment of the plant diversity and community ecology of the Sematan mangrove forest, Sarawak, Malaysia. Forest Ecol Manag 166:111-129

Azariah J, Azariah H, Gunasekaran S, Selvam V (1992) Structure and species distribution in Coringa mangrove forest, Godavari delta, Andhra Pradesh, India. Hydrobiologa 247:11-16

Basha CS (1991) Distribution of mangroves in Kerala. Indian For 117:439-449

Basha CS (1992) Mangroves of Kerala: a fast disappearing asset. Indian For 118(3): 175-190

Beddome RH (1866) The flora of Sylvatica of Southern India. Grantz Bros, Madras, p 862

Blasco F (1975) The Mangroves of India. French Institute, Pondicherry. Trav SCI Tech 4:163

Bosire JO, Dahdouh-Guebas F, Kairo JG, Koedam N (2003) Colonization of nonplanted mangrove species into restored mangrove stands in Gazi Bay, Kenya. Aquat Bot 76:267-279

Bourdillon TF (1908) Forest trees of Travancore. The Travancore Government Press, Trivandrum, p 456

Burns BR, Ogden J (1985) The demography of the temperate mangrove Avicennia marina Forssk. Vierh at its southern limit in New Zealand. Aust J Ecol 10:125-133

Cavalcanti VF, Soares MLG, Estrada ECD, Chaves FO (2009) Evaluating mangrove conservation through the analysis of forest structure data. J Coast Res 56:390-394

Chasang H (1984) Structure of a mangrove forest at Ko Yao Yai, Southern Thailand. In: Soepadmo E, Rao AN, Macintosh DJ (eds) Proceedings of the Asian symposium on mangrove environment research and management. University of Malaya and UNESCO, Kuala Lumpur, pp 86-105

Clarke KR, Gorley RN (2006) PRIMER v6: user manual/tutorial. PRIMER-E, Plymouth

Curtis JT (1959) Vegetation of Wisconsin: An ordination of plant communities. The University of Wisconsin Press, Madison, p 640 
Dislich R, Pivello VR (2002) Tree structure and species composition changes in an urban tropical forest fragment, Sâo Paulo, Brazil during a five-year interval. Bol Bot Univ Sâo Paulo 20:1-11

Drury H (1864) Handbook of Indian flora: Being a guide to all flowering plants, vol 1. Travancore Sircar Press, Trivandrum, p 175

Erlanson EW (1936) A preliminary survey of marine boring organisms in Cochin harbour. Curr Sci 4:726-752

Fromard F, Puig H, Mougin E, Marty G, Betoulle JL, Cadamuro L (1998) Structure and above-ground biomass of mangrove ecosystems: new data from French Guiana. Oecologia 115:39-53

FSI (2015) India State of forest report. Forest Survey of India, Dehradun, p 288

Gamble JS, Fischer CEC (1915-1935) Flora of the Presidency of Madras, 3 vol. Adlard and Son Limited, London, p 2017

Gan BK (1995) A working plan for the Matang Mangrove Forest Reserve. Fourth Revision. The State Forest Department of Perak Darul Ridzuan, Ipoh, p 214

Govinda-Menon K (1930) Indian medicinal plants. Ramanuja Press, Thrissur

Heltshe JF, Forrester NE (1983) Estimating species richness using the jack-knife procedure. Biometrics 39:1-11

Hinrichs S, Nordhaus I, Geist SJ (2009) Status, diversity and distribution patterns of mangrove vegetation in the Segara Anakan lagoon, Java, Indonesia. Reg Environ Change 9:275-289

Holdridge LR (1967) Life Zone Ecology. Tropical Science Center, San Jose

Holdridge LR, Grenke WC, Hatheway WH, Liang T, Tosi JA (1971) Forest environments in tropical life zones: a Pilot study. Pergamon Press, Oxford, p 747

Hooker JD (1872) The flora of British India. 7 Vol. L. Reeve and Co., London

Johnstone IM (1983) Succession in zoned mangrove communities: where is the climax? In: Teas HJ (ed) Tasks for vegetation science 8. Dr W. Junk Publishers, The Hague, pp 131-139

Joshi HG, Ghose M (2003) Forest structure and species distribution along soil salinity and $\mathrm{pH}$ gradient in mangrove swamps of the Sundarbans. Trop Ecol 44:197-206

Joshi HG, Ghose M (2014) Community structure, species diversity, and aboveground biomass of the Sundarbans mangrove swamps. Trop Ecol 55:283-303

Kairo JG, Dahdouh-Guebas F, Gwada PO, Ochieng C, Koedam N (2002) Regeneration status of mangrove forests in Mida Creek Kenya: a compromised or secured future? Ambio 31:562-568

Kathiresan K (2008) Biodiversity of Mangrove Ecosystems. In: Proceedings of Mangrove workshop. GEER Foundation, Gujarat

Kathiresan K, Saravanakumar K, Anburaj R, Gomathi V (2016) A simple method for assessing mangrove forest based on young plants and sesarmid crab holes. Reg Stud Mar Sci 7:204-210

Kauffman JB, Heider C, Cole TG, Dwire KA, Donato DC (2011) Ecosystem carbon stocks of Micronesian mangrove forests. Wetlands 31:343-352

Khaleel KM (2005) Study of the quantitative structure of true mangroves present in the mangal forest of Tellicherry, Pappinisery and Kunhimangalam of Kannur Districts. Indian For 131:81-89

Komiyama A, Ong JE, Poungparn S (2008) Allometry, biomass, and productivity of mangrove forests: a review. Aquat Bot 89:128-137

Krauss KW, Lovelock CE, McKee KL, López-Hoffman L, Ewe SML, Sousa WP (2008) Environmental drivers in mangrove establishment and early development: a review. Aquat Bot 89:105-127

Kurian CV (1980) Fauna of the mangrove swamps on Cochin estuary. In: Proceedings Asian symposium Mangrove Environment research management. University of Malaysia and UNESCO, Kuala Lumpur, pp. 226-230
Levins R (1968) Evolution in changing environments. Some theoretical explorations. Princeton University Press, Princeton, p 120

Lewis RR, Milbrandt EC, Brown B, Krauss KW, Rovai AS, Beever JW, Flynn LL (2016) Stress in mangrove forests: early detection and pre-emptive rehabilitation are essential for future successful worldwide mangrove forest management. Mar Poll Bull 109:764-771

Lovelock CE, Feller Ilka C, Mckee KL, Thompson R (2005) Variation in mangrove forest structure and sediment characteristics in Bocas del Toro, Panama. Caribb J Sci 41:456-464

Macintosh DJ, Ashton EC, Havanon S (2002) Mangrove rehabilitation and intertidal biodiversity: a study in the Ranong mangrove ecosystem, Thailand. Estuar Coast Sci 55:331-345

Maia RC, Coutinho R (2012) Structural characteristics of mangrove forests in Brazilian estuaries: a comparative study. Rev Biol Mar Oceanog 47:87-98

Mandal RN, Naskar KR (2008) Diversity and classification of Indian mangroves: a review. Trop Ecol 49:131-146

Margalef FR (1978) Information theory in ecology. Inter J Gen Syst $3: 36-71$

Mendoza AB, Alura DP (2001) Mangrove structure on the eastern coast of Samar Island, Philippines. In: Stott DE, Mohtar RH, Steinhardt GC (eds) Sustaining the global farm. The 10th international soil conservation, Pardue University and USDAARS, pp 423-425

Menon ARR (2006) Biodiversity characterization at landscape level using satellite remote sensing. DBT-DOS project. Phase-II

Mudailarm CR, Kamath HS (1954) Backwater flora of the West Coast of South India. J Bombay Nat Hist Soc 52:69-82

Murray MR, Zisman SA, Furley PA, Munro DM, Gibson J, Ratter J, Bridgewater S, Minty CD, Place CJ (2003) The mangroves of Belize Part 1 distribution, composition and classification. For Ecol Manag 174:265-279

Nabi A, Brahmaji Rao P, Rama Prasad AV (2012) Analysis of mangrove vegetation of Diviseema region, Krishna district, Andhra Pradesh. Int J Animal Environ Sci 2:99-108

Nameer PO, Mohan Kumar B, Minood CR (1992) Floristics, zonation and above ground biomass production in the mangroves of Puduvyppu, Kerala. Ind J For 15:317-325

Narasimha Rao GM (2012) Distribution pattern and present scenario of mangroves and associated flora of Andhra Pradesh. Biodiversity of aquatic resources. Daya Publishing House, New Delhi, pp 29-49

Pallardy S (2008) Physiology of woody plants. Academic Press, San Diego, p 454

Pellegrini JAC, Soares MLG, Chaves FO, Estrada GCD, Cavalcanti VF (2009) A method for the classification of mangrove forests and sensitivity/vulnerability analysis. J Coast Res 56:443-447

Perera KARS, Amarasinghe MD, Somaratna S (2013) Vegetative structure and species distribution of mangroves along the soil salinity gradient in a micro tidal estuary on the Noth-Western coast of Sri Lanka. Am J Marine Sci 1:7-15

Pichi-sermolli R (1948) An index for establishing the degree of maturity in plant communities. J Ecol 36:85-90

Pielou EC (1966) The measurements of diversity in different types of biological collections. J Theo Biol 13:131-144

Polidoro BA, Carpenter KE, Collins L, Duke NC, Ellison AM, Ellison JC, Farnsworth EJ, Fernando ES, Kathiresan K, Koedam NE, Livingstone SR, Miyagi T, Moore GE, Ngoc Nam V, Ong JE, Primavera JH, Salmo SG, Sanciangco JC, Sukardjo S, Wang Y, Yong JW (2010) The loss of species: mangrove extinction risk and geographic areas of global concern. PLoS ONE 5:1-10

Pool DJ, Snedaker SC, Lugo AE (1977) Structure of mangrove forests in Florida, Puerto Rico, Mexico, and Costa Rica. Biotropica 9:195-212 
Ragavan P, Saxena A, Mohan PM, Ravichandran K, Jayaraj RSC, Saravanan S (2015) Diversity, distribution and vegetative structure of mangroves of the Andaman and Nicobar Islands, India. J Coast Conserv 19(4):417-443

Ragavan P, Saxena A, Jayaraj RSC, Mohan PM, Ravichandran K, Saravanan S, Vijayaraghavan A (2016) A review of the mangrove floristics of India. Taiwania 61:224-242

Rahees N, Kiran M, Vishal V (2014) Phytosociological analysis of mangrove forest at Kadalundi-Vallikkunnu community reserve, Kerala. Inter J Sci Tech 3:2154-2159

Rama Rao M (1914) Flowering plants of Travancore. Government Press, Trivandrum, p 511

Ramachandran KK, Mohanan CN (1987) Perspectives in management of mangroves of Kerala with special references to Komarakom mangroves a bird sanctuary. In: Proceedings national seminar estuarine management, pp 252-257

Ramachandran KK, Mohanan CN, Balasubramonian G, Kurten L, Thomas L (1986) The mangrove ecosystem of Kerala; its mapping, inventory and some environmental aspects. Centre for Earth Science Studies, Trivandrum, p 38

Rani V, Sreelekshmi S, Asha CV, Bijoy Nandan S (2016) Forest structure and community composition of Cochin mangroves, south-west coast of India. Natl Acad Sci. https://doi.org/10.1007/ s40011-016-0738-7

Rao TA, Sastry ARK (1974) An Ecological approach towards classification of Coastal vegetation in India, II. Estuarine border vegetation. Indian For 100:438-452

Robertson AI, Daniel PA, Dixon P (1991) Mangrove forest structures and productivity in the Fly River estuary, Papua New Guinea. Mar Biol 111:147-155

Satyanarayana B, Raman AV, Dehairs F, Kalavati C, Chandramohan P (2002) Mangrove floristics and zonation pattern of Coringa, Kakinada Bay, East coast of India. Wetl Ecol Manag 10:25-39

Satyanarayana B, Raman AV, Mohd-Lokman H, Dehairs F, Sharma VS, Farid DG (2009) Multivariate methods distinguishing mangrove community structure of Coringa in the Godavari Delta, east coast of India. Aquat Ecosyst Health 12:401-408

Satyanarayana B, Idris IF, Mohamad KA, Husain ML, Shazili NAM, Dahdouh-Guebas F (2010) Mangrove species distribution and abundance in relation to local environmental settings: a casestudy at Tumpat, Kelantan Delta, east coast of peninsular Malaysia. Bot Mar 53:79-88

Sawale A, Thivakaran GA (2013) Structural Characteristics of Mangrove Forest of Kachchh, Gujarat. J Mar Assoc India 55:5-11

Shah K, Mustafa Kamal AH, Rosli Z, Hakeem KR, Hoque MM (2015) Composition and diversity of plants in Sibuti mangrove forest, Sarawak, Malaysia. For Sci Technol 12:70-76

Shannon CE, Weaver W (1963) The mathematical theory of communication. University of Illinois Press, Urbana, p 125

Simpson EH (1949) Measurement of diversity. Nature 163:688
Singh VP, Odaki K (2004) Mangrove ecosystems: structure and function. Scientific Publishers, Jodhpur, p 297

Singh VP, Mall LP, Garge A, Pathak SM (1990) Human impact assessment on mangrove forests of Andaman Islands. Indian For 176:131-139

Srivastava PBL, Bal HS (1984) Composition and distribution pattern of natural regeneration after second thinning in Matang mangrove reserve, Perak Malaysia. In: Soepadimo E, Rao AN, Macintosh DJ (eds) Proceedings of the asian symposium on mangrove environment: research managements, Kuala Lumpar, pp 761-784

Suresh Kumar S, Mohan Kumar B (1997) Floristics, biomass production and edaphic attributes of the mangrove forests of Puduvyppu, Kerala. Ind J For 20:136-143

Thomas KJ (1962) A Survey on vegetation of Veli, Trivandrum with special references to ecological factors. J Indian Bot Soc 42:104-131

Trettin CC, Stringer CE, Zarnoch SJ (2016) Composition, biomass and structure of mangroves within the Zambezi River Delta. Wetl Ecol Manag 24:173-186

Troup RS (1921) The silivicultutre of Indian trees, 3 Vol. The Clarendon Press, Oxford, p 1195

Twilley RR (1995) Properties of mangrove ecosystems related to the energy signature of coastal environments. In: Hall CAS (ed) Maximum power: the ideas and application of Odum HT. University of Colorado Press, Colorado, pp 43-62

Twilley RR (1998) Mangrove wetlands. In: Messina M, Connor W (eds) Southern forested wetlands: ecology and management. CRC Press, Boca Raton, pp 445-473

Upadhyay VP, Mishra PK (2014) An ecological analysis of mangroves ecosystem of odisha on the eastern coast of India. Proc Nat Acad Sci 80:647-661

Van Nguyen T, Le Nhu H, Lin SM, Steen F, De Clerck O (2013) Checklist of the marine macroalgae of Vietnam. Bot Mar 56:207-227

Van Rheede HA (1678-1693) Hortus Indicus Malabaricus, vol 12. Sumptibus Johannis van Someren et Joannis van Dyck, Amsterdam

Venkanna P, Narasimha Rao GM (1993) Distribution pattern of the Mangroves in the Krishna estuary. Indian J For 16:48-53

Vidyasagaran K, Madhusoodanan VK (2014) Distribution and plant diversity of mangroves in the west coast of Kerala, India. J Biodiv Environ Sci 4:38-45

Vijayan V, Rahees N, Vidyasagaran K (2015) Plant diversity and structural dynamics of mangroves in the southwest coast of Kerala, India. Appl Ecol Env Res 1:1055-1067

Whitmore TC (1988) Tropical rain forests in the Far East, 2nd edn. Oxford Science Publications, Oxford, p 376

Whittaker RH (1972) Evolution and measurement of species diversity. Taxon 21:213-251 